\title{
Investigation of Hepatitis A, B and C Serology Among Civil Defense Workers and Comparison with the Normal Population
}

\author{
Sivil Savunma Uzmanlarında Hepatit A, B ve C Serolojisinin Araștıılması ve Normal Popülasyon \\ ile Karșllaștırlması
}

\author{
Semiha SOLAK GRASSIE1, Fatih OCAK2, Bircan KAYAASLAN1 \\ ${ }^{1}$ YIldırım Beyazı University Yenimahalle Teaching and Research Hospital, Clinic of Infectious Disease and Clinical Microbiology, Ankara, Turkey \\ 2 Yıldırım Beyazıt Universtiy Yenimahalle Teaching and Research Hospital, Clinic of Microbiology, Ankara, Turkey
}

\begin{abstract}
Objective: Civil defense workers function during natural disasters, wars and disease outbreaks. They live in poor conditions during their work and are often exposed to blood and body fluids. Hepatitis is still an important health problem in our country with some occupational groups being possibly at greater risk. We set out to investigate hepatitis $\mathrm{A}, \mathrm{B}$ and $\mathrm{C}$ serology among the civil defense workers and determine whether they are at greater risk for hepatitis than the normal population. Materials and Methods: In this study conducted in December 2012, we investigated hepatitis $A, B$ and $C$ serology in 125 civil workers employed by the Department of Disaster and Emergency Management in Ankara. Serological tests were performed using direct chemiluminescence sandwich immune test with ADVIA Centaur XP System Siemens Healthcare Diagnostics (Tarrytown, NY.) The subjects were questioned about their hepatitis $A$ and $B$ vaccination history. Workers without immunity against hepatitis $A$ and $B$, according to serological test results, were vaccinated

Results: Of the civil defense workers, $93.6 \%$ were male and the mean age was $36.6 \pm 7.8(22-58)$ years. HBsAg positivity rate was $0.8 \%$ and anti-HBs positivity rate was $49.6 \%$. The rate of hepatitis $B$ vaccination history among anti-HBs-positive subjects was $95.2 \%$. Anti hepatitis $A$ virus (anti-HAV) lgG positivity rate was $84 \%$ and none of them had a history of vaccination. Anti hepatitis $\mathrm{C}$ virus (anti-HCV) positivity was not determined to be present in any of the participants. Age was statistically significantly correlated with anti-HBs and anti-HAV IgG positivity $(p=0.001, p=0.000$, respectively). No relationship was detected between age and natural immunity.

Conclusion: The rates for hepatitis $A, B$ and $C$ were similar with the normal population according to age interval. When compared with healthcare workers, the group had lower HBsAg positivity and hepatitis $B$ vaccination rate. Although the civil defense workers had contact with blood and body fluids and had worked in poor conditions, they did not have a higher hepatitis rate than the normal population. In spite of these results, it seems advisable that they have hepatitis $A$ and $B$ vaccination and personal protection equipment against the risk of exposure to blood and body fluids.
\end{abstract}

Keywords: Hepatitis A, hepatitis B, hepatitis C, seroprevalence

\section{ÖZ}

Amaç: Sivil savunma uzmanları; doğal felaketler, savaşlar ve salgınlar sırasında görev yapmaktadırlar. Çalışmaları sırasında sağlıksız koşullarda yaşamakta; sık sık kan ve vücut sıvıları ile temas etmektedirler. Hepatitler ülkemizde halen önemli bir sağlık sorunu olup bazı meslek grupları hepatitler açısından risk altında bulunmaktadır. Biz bu çalışmada sivil savunma uzmanlarının hepatit $A, B$ ve $C$ serolojisini araștırmayı ve hepatit açısından topluma göre yüksek riskli bir grup olup olmadıklarını belirlemeyi amaçladık.

Gereç ve Yöntemler: Aralık 2012'de yapılan bu çalışmada, Ankara'da, Afet ve Acil Durum Yönetimi Başkanlığı'nda çalışan 125 sivil savunma uzmanının hepatit A, B ve C serolojisi araştıııldı. Serolojik metot olarak ADVIA Centaur direkt kemilüminometrik sandviç immün testi kullanıldı. Uzmanların hepatit A ve B ile aşılanma öyküleri sorgulandı. Serolojik çalışma sonucunda hepatit A ve B'ye karşı bağışıklığı olmayan çalışanların aşılanması sağlandı.

Bulgular: Çalışılan sivil savunma uzmanlarının \%93,6'sı (117) erkek, ortalama yaş $36,6 \pm 7,8$ (22-58) yıl idi. HBsAg pozitifliği \%0,8, anti-HBs pozitifliği \%49,6, anti-HBs pozitif olanlardan hepatit B'ye karşı aşıSı öyküsü olanların oranı $\% 95,2$ idi. Anti hepatit $A$ virüs (anti-HAV) IgG pozitifliği \%84 idi ve hiçbirinin hepatit A'ya karşı aşılanma öyküsü yoktu. Hiçbirinde anti hepatit $\mathrm{C}$ virüs (anti-HCV) pozitifliği tespit edilmedi. Yaş ile anti-HBs ve anti-HAV IgG pozitifliği arasında istatistiksel olarak anlamlı pozitif bir korelasyon tespit edildi ( $p$ değeri sırasıyla $p=0,001,0,000$ ). Yaş ile doğal bağışıkık arasında bir ilişki saptanamadı.

Sonuç: Sivil savunma uzmanlarında hepatit $A, B$ ve $C$ oranları toplumda benzer yaş grubunda görülen oranlarla uyumlu olarak bulundu. Sağlık çalışanları ile karşılaștııııdığında HBsAg pozitiflik oranı ve hepatit B'ye karşı aşılanma oranları daha düşük olarak bulundu. Hepatit oranları toplumda rastlanan oranlara göre yüksek tespit edilmese de sivil savunma uzmanlarının doğal felaketler, savaşlar ve salgınlar sırasında olumsuz koșullarda yaşamaları, kan ve vücut sıvıları ile temas risklerinin bulunması nedeniyle hepatit A ve B'ye karşı aşılanmalarının ve vücut sıviları ile temas riski olan durumlarda koruyucu ekipman kullanmalarının daha uygun olduğunu düşünmekteyiz.

Anahtar Kelimeler: Hepatit A, hepatit B, hepatit C, seroprevalans 


\section{Introduction}

Civil defense workers function during extraordinarily difficult times such as natural disasters, wars and disease outbreaks to do help and rescue in our country. They have to live and work in poor condition as a matter of course during these times. Sometimes they have to go outside the country to help people. They contact many people in poor and non-hygienic conditions resulting in risk of exposure to blood and body fluids.

Hepatitis is still an important health problem in our country. Especially hepatitis $A$ and $B$ are still common among the population $(1,2)$. In the adult population, anti-HAV IgG positivity rate is between $72.4 \%$ and $100 \%$ (2). Hepatitis $A$ is transmitted to humans via the fecal-oral route in inappropriate sanitation conditions. This is a common problem for populations of poor socio-economic conditions.

Hepatitis B virus (HBV) is transmitted through exposure to infective blood and body fluids. Individuals in some occupational groups like healthcare workers and police officers have a higher risk for hepatitis B than the normal population (1). Before the national vaccination programs have been implemented and awareness of protection methods has been increased, healthcare workers had a higher hepatitis $B$ rate than the normal population (1). The rate of HBsAg positivity in healthcare workers in the last decade was found to be similar to that in the normal population (1). Civil defense workers might have an increased occupational risk for hepatitis as a result of poor working conditions which increase the risk of exposure to blood and body fluids. There is not much research about the epidemiology of hepatitis among civil defense workers.

In this study, we aimed to analyze hepatitis A, B and C status of civil defense workers and to investigate whether they have a higher occupational risk for hepatitis $A, B$ and $C$ compared to the normal population.

\section{Materials and Methods}

This study was carried out in the clinics of infectious disease and clinical microbiology at Yenimahalle Education and Research Hospital in December 2012. A total 125 civil defense workers, who were employed at the Department of Disaster and Emergency Management, were included in the study. Demographical features and the history of hepatitis $A$ and $B$ vaccination were recorded on a special form. The workers were investigated for hepatitis $A$, $B$ and $C$ serology. Serological tests were performed using direct chemiluminescence sandwich immune test with ADVIA Centaur XP System Siemens Healthcare Diagnostics (Tarrytown, NY) in the microbiology laboratory at our hospital. After the serological tests, the employees who did not have immunity against hepatitis $A$ and $B$ were vaccinated.

\section{Results}

One hundred twenty five civil defense workers were included in the study. The mean age of the subjects was 36.6 7.8 (2258) years, $93.6 \%$ was male. HBsAg positivity rate was $0.8 \%$ and anti-HBs positivity rate was $49.6 \%$. Of the anti-HBs-positive workers, 95.2\% reported having hepatitis B vaccine. The workers with anti-HBs positivity without a history of vaccination were accepted as having natural immunity against hepatitis B. Anti-HAV IgG was positive in $84 \%$ of the workers. None of these had a history of hepatitis A vaccination. Anti-HCV positivity was not detected among the workers. There was a statistically significant positive correlation between age and anti-HBs positivity $(p=0.001$, correlation coefficient 0.295$)$. A significant correlation was detected also between age and anti-HAV IgG positivity $(p=0.000$, correlation coefficient: 0.357). There was no significant correlation between age and natural immunity to hepatitis $B(p=0.09)$. The civil defense workers without immunity received the vaccination, 17 of them received hepatitis $A$ vaccine and 63 of them received hepatitis $B$ vaccine.

\section{Discussion}

The prevalence of hepatitis A has been decreasing in our country especially among the young population as a result of better infrastructure and hygienic life (2). However, civil defense workers sometimes work in negative conditions, such as natural disasters, wars and disease outbreaks, in which sanitation and clean drinking water may not be provided. As a result, they have a possible risk for exposure to hepatitis A. We detected the anti-HAV IgG positivity rate of $84 \%$, among civil workers and this was similar to that in the normal population which has been reported as $86 \%$ among those older than 25 years living in Ankara (2). People working in waste management industry and wastewater workers and recyclable waste pickers as well as daycare providers and hospital workers also have an occupational risk for hepatitis $A(3,4,5,6,7,8)$. The civil defense workers seemed to have no increased risk for hepatitis $A$ compared to the normal population. There is an increased risk for hepatitis A among the occupational groups working in poor hygienic conditions and the civil defense workers work in similar condition $(6,7)$. Our rate of hepatitis $A$ is similar to normal population rates but we think this occupational group should be accepted as a group having an increased risk for hepatitis $A$ and if they are not immune, hepatitis A vaccine should be done because exposure to hepatitis $A$ in advanced age is associated with increased morbidity and mortality rates (9).

HBsAg positivity rate among civil defense workers was detected to be $0.8 \%$; this result is compatible with the previous studies reported from our country. According to data from the Turkish Red Crescent Blood Center, this rate among blood donors

Tablo 1. Hepatitis serology test results of the civil aid workers

\begin{tabular}{|l|c|c|c|c|c|}
\hline & HBsAg $n \%$ & Anti-HBs $n \%$ & Natural immunity hepatitis B $\mathrm{n} \%$ & Anti-HAV IgG $\mathrm{n} \%$ & Anti-HCV $\mathrm{n} \%$ \\
\hline The civil aid workers $(\mathrm{n}) 125$ & $1(0.8 \%)$ & $62(49.6 \%)$ & $6(4.8 \%)$ & $105(84 \%)$ & 0 \\
\hline
\end{tabular}

Anti-HAV: Anti hepatitis A virus, Anti-HCV: Anti hepatitis $\mathrm{C}$ virus 
was $1.7 \%$ in 2008, 1.1\% in 2010 and $0.6 \%$ in $2012(1,10)$. HBsAg positivity rate among healthcare workers in Ankara was $1.6 \%$ in 2011 which was higher than what we found among civil defense workers (1). HBsAg positivity rate among civil defense workers was found to be similar to that in the normal population. In some research, the rate among soldiers, who have similar work conditions with civil defense workers, was reported to be higher than in the normal population (6.8\%) (11). Tosun (1) reported that HBsAg rate was between $1.3 \%$ and $13.6 \%$ and anti-HBs rate was between $10.1 \%$ and $46.1 \%$ among the different segments and geographical regions in our country according to the research done in the last decade (12). The rates we found are close to the lower limit of the range published before. In our study, the antiHBs positivity rate was $49.6 \%$. This rate is lower than the rate in healthcare workers which was $79.3 \%$ (1). Natural immunity rate was $1.4 \%$ in 2011 in healthcare workers in Ankara (1). Our civil defense worker group had $4.8 \%$ natural immunity rate which was higher than that in healthcare workers in Ankara although it has been reported in different research to be between $2.1 \%$ and $7.5 \%$ among health workers in a different time and region (1). In different research, the rate of natural immunity in the normal population has been reported to be between $2.1 \%$ and $30.1 \%$ (1). The civil defense worker group had a lower vaccination rate but a higher natural immunity rate compared to healthcare workers. This result demonstrates the importance of encouraging them to get vaccinated against hepatitis B. There have been some studies investigating the risk of occupational exposure to hepatitis among firefighters and public safety workers $(13,14,15,16)$. These groups have working conditions similar to that of civil defense workers and have similar risks. In a study by Averhoff et al., (13) of the 2910 public safety workers included in the study, $1 \%$ reported exposure to needle stick injury, $2.8 \%$ to stab injuries caused by items contaminated with blood and $0.9 \%$ reported mucous membrane exposure to blood in the previous 6 months. Hepatitis B risk was not determined to be higher in these groups than in the normal population. However, employees reporting skin contact with blood had been reported to have higher infection risk with hepatitis $B$ and $C$ than employees not reporting any contact. Therefore, hepatitis $B$ vaccination was suggested for these groups. This result might suggest that civil defense workers should use protection equipment and get vaccinated against hepatitis B. $(13,14)$. In our research, we did not determine a history of injury with tools and needle sticks. Further research investigating hepatitis serology among civil defense workers with a history of contact might be helpful in understanding the risk.

Anti-HCV positivity rate has been reported to be $0.5 \%$ in the normal population in Turkey. People older than 50 years of age were detected to have a higher hepatitis $\mathrm{C}$ rate than younger individuals (17). In our study, anti-HCV antibody was not detected among the civil defense workers. This may be due to the small number of subjects evaluated in our study compared to the normal population studies or due to studying with younger group. The 30-year cumulative risk for hepatitis $C$ for firefighters was found to be lower than $0.1 \%(16)$. It has been determined that there was no increased occupational risk for acquiring hepatitis $\mathrm{C}$ among firefighters $(14,15)$. Healthcare workers also had no increased hepatitis $C$ rate which might be the result of increased awareness, precautions and protection (17). It is important to remember that contact without protection still might cause increased risk of hepatitis $\mathrm{C}$. There is no vaccine for hepatitis $\mathrm{C}$ and the main protection method is protection equipment against the risk.

The relationship between age and anti-HAV IgG is a wellknown reality in our country. In the future, we might see more adults without immunity which is an important consideration for risk assessment. Anti-HBs relation to age depend on experience and vaccination. There is no relationship between age and natural immunity. There are other factors affecting hepatitis B infection transmission like possible risky behavior or protection methods use that we did not find out.

In our research, the civil defense workers had the similar $\mathrm{HBsAg}$, anti-HAV IgG and anti-HCV rates with the normal population at the similar age interval. Hepatitis B vaccination rate among the civil defense workers was lower than in healthcare workers and none of them had hepatitis A vaccination. However, because they have the risk of exposure to blood and body fluids and work sometimes in conditions of poor sanitation, they should get vaccinated against hepatitis $A$ and $B$. They should be educated about hepatitis infections and instructed to use personal protective equipment in situations with risk of exposure to blood and body fluids through skin and mucous membranes.

\section{Authorship Contributions}

Ethics Committee Approval: The study weren't approved by any Ethics Committee, Informed Consent: Consent form was filled out by all participants, Concept: Semiha Solak Grassie, Fatih Ocak, Bircan Kayaaslan, Design: Semiha Solak Grassie, Data Collection or Processing: Semiha Solak Grassie, Fatih Ocak, Analysis or Interpretation: Semiha Solak Grassie, Bircan Kayaaslan, Literature Search: Semiha Solak Grassie, Writing: Semiha Solak Grassie, Peer-review: Externally peer-reviewed, Conflict of Interest: No conflict of interest was declared by the authors, Financial Disclosure: The authors declared that this study has received no financial support.

\section{References}

1. Tosun S. Türkiyede Viral Hepatit B Epidemiyolojisi Yayınların Metaanalizi. Tabak F, Tosun S, Viral Hepatit. Istanbul: Istanbul Medikal Sağlık ve yayıncılık; 2013.p.27-80.

2. Mıstık R .Hepatit A Virüs Enfeksiyonunun Epidemiyolojisi. Tabak F, Tosun S, Viral Hepatit. Istanbul: Istanbul Medikal Sağlık ve yayıncılık; 2013.p.15-23.

3. Rachiotis G, Papagiannis D, Thanasias E, Dounias g, Hadjiichristodoulou C. Hepatitis A virus infection and waste handling industry: a seroprevelance study. Int I Environ Res Public Health. 2012;9(12):4498-4503.

4. Divizia M, cencioni B, Palombi L, Pana A. Sewage workers :risk of acquiring enteric virus infections including hepatitis $A$. New Microbiol. 2008;31(3):337-341.

5. Dounias G, Rachiotis G. Prevelance of hepatitis a virus infection among municipal solid-waste workers. Int J Clin Pract. 2006;60(11):1432-1436.

6. Keeffe EB. Occupational risk for hepatitis A:literature-based analysis. J Clin Gastroenterol. 2004;38(5):440-448.

7. Chodic G, Ashkenazi S, Aloni H, Peled T, Lerman Y. Hepatitis A virus seropositivity among hospital and community healthcare workers in israel- the role of occupation, demography and socioeconomic backround. J hosp Infect. 2003;54(2):135140. 
8. Peled T, Ashenazi S, Chodick G, Aloni H, Yuhas $Y$, Lerman $Y$. Risk of exposure to hepatitis A virus among day-care workers in israel: implications for preventive measures. Arch Environ Health. 2002;57(4):332-336.

9. Tosun S. Hepatit A Enfeksiyonu. Tabak F, Tosun S, Viral Hepatit. Istanbul: Istanbul Medikal Sağlık ve yayıncılık; 2013.p.217-246.

10. Dinç B, Karabiber N, Yagcı S, Arca EA, Gürbüz A, Tolunay EA. Türkiye yüksek ihtisas eğitim ve araştırma hastanesinde kan donörlerinin serolojik profili. Türk Hyjen ve Deneysel Biyoloji Dergisi. 2011;68(1):17-22.

11. Emiroğlu HH. Asker Ve Sivillerde Hepatit B Virüs Taşıyıcılığı Şırnak Türkiye. Viral Hepatit Dergisi. 2013;19:92.

12. Mıstık R. Türkiyede Viral Hepatitlerin Epidemiyolojisi Yayınların Irdelenmesi. Tabak F, Balık I, Tekeli E. Viral Hepatit .2007.p.9-50.

13. Averhoff FM, Moyer LA, Woodruff BA, Deladisma AM, Nunnery $\mathrm{J}$, Alter MJ, Margolis HS. Occupational exposure and risk of hepatitis B virus infection among public safety workers. J Occup Environ Med. 2002;44(6):591-596.

14. Rischitelli G, Harris J, McCauley L, Gershon R, Guidotti T. The risk of acquiring hepatitiis $\mathrm{B}$ or $\mathrm{C}$ among public safety workers : a systematic review. Am J Prev Med. 2001;20(4):299-306.

15. Upfal MJ, Naylor P, Muthnic MM. Hepatitis C screening and prevelance among urban public safety workers. J Occup Environ Med. 2001;43(4):402-411.

16. Rischitelli G, Laserey M, McCauley L. Career risk of hepatitis C virus among U.S. emergency medical public safety workers. J Occup Environ Med. 2005;47(11):1174-1181.

17. Mıstık R. Hepatit C Virüs Enfeksiyonunun Epidemiyolojisi. Tabak F, Tosun S,Viral Hepatit. Istanbul: Istanbul Medikal Sağlık ve yayıncılık; 2013.p.81-112. 